\title{
WHO BENEFITS FROM TEAMS? COMPARING WORKERS, SUPERVISORS, AND MANAGERS
}

Final June, 2003

\section{Forthcoming, Industrial Relations}

\author{
ROSEMARY BATT \\ Alice Cook Professor of Women \& Work \\ Department of Human Resource Studies \\ New York State School of Industrial Labor Relations \\ Cornell University \\ Ithaca, NY 14853-3901 \\ Tel: (607) 254-4437 \\ Fax: (607) 255-18 \\ E-mail: rb41@cornell.edu
}




\title{
WHO BENEFITS FROM TEAMS? \\ COMPARING OUTCOMES FOR WORKERS, SUPERVISORS, AND MANAGERS
}

\author{
Abstract \\ This paper offers a political explanation for the diffusion and sustainability of team-based \\ work systems by examining the differential outcomes of team structures for 1200 workers, \\ supervisors, and middle managers in a large unionized telecommunications company. \\ Regression analyses show that participation in self-managed teams is associated with \\ significantly higher levels of perceived discretion, employment security, and satisfaction for \\ workers and the opposite for supervisors. Middle managers who initiate team innovations report \\ higher employment security, but otherwise are not significantly different from their counterparts \\ who are not involved in innovations. By contrast, there are no significant outcomes for \\ employees associated with their participation in offline problem-solving teams.
}




\section{WHO BENEFITS FROM TEAMS? COMPARING WORKERS, SUPERVISORS, AND MANAGERS}

A growing body of research shows that the use of self-managed or semi-autonomous teams is associated with better performance, but there is much less support for a link between offline-line problem-solving teams or quality circles and performance (Cotton et al., 1993; Guzzo and Dickson, 1996; Cohen and Bailey, 1997). Yet despite this empirical evidence, the use of self-managed teams in U.S. firms appears to have plateaued in the late 1990s, while quality circles have diffused considerably. In two rounds of surveys of a nationally representative sample of establishments, for example, Osterman (2000) found that the use of self-managed teams fell from 40.5 percent of establishments in 1992 to 38.4 percent in 1997; but quality circles almost doubled in use, from 27.4 percent to 57.7 percent. What accounts for this paradox?

Existing research on teams fails to account for this paradox for two reasons. First, researchers have focused primarily on performance outcomes of teams in order to build the business case for their use. This approach assumes that sustainability and diffusion of team structures depend on managers making economically rational decisions: if teams lead to better operational performance, then their use will expand. However, sustainability and diffusion depend upon political as well as economic factors: that is, firms depend on the discretionary effort or goodwill of employees to successfully implement teams. To the extent that team structures fail to meet the self-interests of employees responsible for actual implementation, employees have incentives to undermine or thwart implementation. Second, team researchers have focused almost entirely on teams as the unit of analysis. They have not examined the system as a whole -- how teams change the social division of labor and how these changes differentially affect the self-interests of non-managerial employees, supervisors, and managers. 
This study examines one set of factors that help explain the sustainability and diffusion of different types of team structures: the relative effects of those structures on the self-interests of workers, supervisors, and managers. I contribute to the literature in three ways. First, rather than focus on workers as the subject of research, I examine how team structures change the division of labor among workers, supervisors, and managers. Also, in contrast to prior studies, which tend to lump supervisors and middle managers together, I consider their outcomes separately. Second, I examine outcomes associated with two types of team structures: selfmanaged teams and offline problem-solving teams (quality circles, quality action teams), based on the idea that these two team structures affect the division of labor in quite different ways. Third, I examine how team participation affects the self-interests of employees (employment security, decision-making discretion, and satisfaction) as well as their support for team structures. I hypothesize that self-managed teams and offline problem-solving teams will have different effects on the interests of these groups, and that support for team structures will depend on how the interests of each group are affected.

To study these questions, I chose a "best case” example of union-management cooperation in the U.S. The union and management in this case had a mature bargaining relationship and negotiated union and employee participation in offline problem-solving and self-managed teams (SMTs) to improve firm competitiveness. The study draws on qualitative field research and a survey of a stratified random sample of 1,191 employees in a regional Bell operating company (RBOC).

\section{PREVIOUS LITERATURE}

Most research on teams has used a psychological or behavioural paradigm to understand how group task design, processes, and rewards affect worker attitudes and performance. The 
focus on the team as the unit of analysis has meant that researchers rarely examine the relationship between team members and other occupational groups. Exceptions include Manz and colleagues' research on the leadership role of supervisors (Manz and Sims, 1987; Stewart and Manz, 1997) and Ancona and colleagues' research on teams and their relations with external groups (Ancona and Caldwell, 1992). However, even in these instances, the focus remains on teams as the unit of analysis and team performance as the dependent variable of interest. As a result, the research in organizational behavior has not examined teams as components of systems of production and how different team structures reshape the division of labor between workers, supervisors, and managers.

In the industrial relations tradition, the literature on high performance work systems has taken a "systems" approach to examining human resource practices, and team-based work structures usually figure prominently as one dimension of the high performance system. However, in their focus economic performance (Ichniowski et al., 1996), researchers in this arena also have not examined the specific ways in which high performance systems affect the division of labor and individual outcomes for workers, supervisors, and managers.

An alternative approach is to examine production systems as political-economic systems in which conflict and cooperation are on-going processes through which the self-interests of actors are realized. In classic accounts of the game of "making-out" in piece-rate systems, for example, workers met quotas but restricted output in an on-going game of maximizing their pay while minimizing the risk that the rate per piece would be adjusted downwards. Supervisors colluded in the game so long as their authority was not threatened and production quotas were met, ensuring job security for both workers and supervisors (Roy 1953). Building on this tradition, Burowoy (1979) formalized a theory of the labor process in which he argued that "the 
game" played by workers and supervisors is a metaphor for a set of rules that emerge historically out of struggle and bargaining, conflict and cooperation. Workers and managers seek to get their individual needs met within the economic constraints imposed by the production process. Each change in the production system -- the reassignment of workers to different jobs, the ratcheting up of quotas, and the like -- induces conflict or bargaining over new rules of the game and how each party will get their needs met.

The introduction of teams in the production system is one example of change that disrupts the existing rules of the game by altering the division of labor. Different types of team structures, however, have different implications for the division of labor. Two types of team structures distinguished in the literature are "on-line" self-managed teams and "off-line" teams. Leana (1987), for example, distinguishes between “delegation” and "participation”: the former involves shifting decision-making from higher to lower level employees while the latter involves shared consultation between managerial and non-managerial employees. Similarly, Levine and Tyson (1990) differentiate between substantive participation (as in on-line or production teams) and consultative participation (as in offline quality circles, quality action teams, or problemsolving groups). Lawler et al (1995) distinguish between "work design power-sharing arrangements" and "parallel structures", with the latter defined as parallel to or outside of the formal structure of authority and organization of work. In the sections below, I review the theories and evidence regarding how each type of team structure differentially affects the division of labor and the self-interests of workers, supervisors, and managers.

\section{Self-managed Teams and Employee Outcomes}

In this paper, I use the term self-managed teams to include autonomous or semiautonomous work groups: those with considerable discretion over work-related decisions. In 
reality, there is considerable variation in the types of decisions these teams can make. In theory, the introduction of self-managed teams fundamentally changes the division of labor in traditional hierarchies. In hierarchical organizations, decision-making authority flows from the top down, and an employee's level in the hierarchy defines the content of work, responsibility, pay, trust, employment security, and attitudes such as satisfaction and commitment (e.g., Mowday, Porter, and Steers, 1982; Lincoln and Kalleberg, 1990). The introduction of self-managed teams into hierarchical organizations redefines the division of labor between workers and supervisors in two ways. First, considerable responsibility for operational decisions is shifted from supervisors to groups of workers. Second, responsibility for monitoring and coordination is shifted from supervisors to groups of workers, leaving supervisors with broader spans of control and "coaching" responsibilities. In theory, this change in the division of labor creates a more effective production system (use of direct labor) because workers with tacit knowledge closest to the point of production are making operational decisions. In theory, the change also creates a more efficient organizational structure because indirect labor functions (of monitoring and control) are integrated into direct labor functions. Third-party transactions costs (supervisory positions) are reduced. As Guzzo and Dickson (1996) noted, the concept of autonomous teams has been around for 50 years, but "there was little momentum for their adoption in US workplaces until the past decade or so as firms reduced levels of management...." (1996:324). The growing view, therefore, is that self-managed teams not only for improve worker performance, as in theories of group effectiveness (Hackman, 1987) and socio-technical systems (STS) (Pearce and Ravlin, 1987), but provide an explicit strategy for reducing bureaucracy and delayering management. 
These changes in the division of labor have important implications for the self-interests of workers and supervisors. First, in day-to-day production activities, workers in self-managed teams should experience higher levels of decision-making discretion, while their supervisors are removed from the process. In the game analogy, supervisors are now one step removed from the game, and experience a loss of decision-making discretion, even (or especially) when their new jobs are redefined as "coaching". Second, workers' absorption of activities previously done by supervisors is likely to increase their relative importance to the organization and, hence, their sense of employment security. By contrast, some supervisors lose their jobs, while those that remain are likely to feel threatened that their jobs over time will be eliminated while supervisors are removed from the process.

Thus, the shift to self-managed teams affects two specific dimensions of the jobs of workers and supervisors: their decision-making discretion and their employment security. These dimensions, in turn, are likely to influence employees' overall satisfaction with their jobs and with the company.

Empirical studies provide some support for this scenario. Literature reviews by Pasmore et al. (1982), Cotton (1993), and Cohen and Bailey (1997) contain positive assessments that workers gain discretion and are more satisfied in self-managed or semi-autonomous groups than in traditionally supervised settings. It should be noted that the results for workers are more mixed when other types of outcomes (absenteeism, turnover, stress) are examined (Wall et al. 1986; Cordery, Mueller, \& Smith 1991; Barker 1993; Appelbaum et al. 2000). However, I could find no quantitative studies of the relationship between team participation and employment security, although Osterman (2000) recently reported that establishments with high performance systems had higher rates of downsizing than their more traditional counterparts. 
In contrast to the extensive research on teams and workers, the literature on supervisory outcomes is quite thin and comes primarily from qualitative case studies of manufacturing plants that introduced self-managed teams. Those case studies, however, do support the idea that it is reductions in decision-making discretion and employment security that lead supervisors to be dissatisfied and resist or sabotage self-managed team innovations (e.g., Buchanan and Preston, 1991; Emery, 1980; Klein, 1984; Muller-Jentsch, 1995; Schlesinger, 1982; Schlesinger and Klein, 1987; Walton and Schlesinger, 1979; Heller et. al. 1998: 203). One quantitative study of self-managed teams in manufacturing does not support these arguments. Denison (1982) compared supervisors and workers in a self-managed team-based plant and found that both were more satisfied with their jobs than were their counterparts in a hierarchically-organized plant. Overall, however, theory and prior case research suggest that self-managed team innovations decrease the discretion and employment security of supervisors, which in turn leads to dissatisfaction and resistance to these organizational changes.

In sum, prior research on teams in organizations suggests 2 hypotheses: H1: For workers, participation in self-managed teams has a significant positive relationship with their perceptions of decision-making discretion, employment security, and satisfaction. For supervisors, involvement with self-managed teams is significantly negatively related to their perceptions of discretion, employment security, and satisfaction.

H2: For workers and supervisors, discretion and employment security mediate the relationship between team participation and individual satisfaction.

For middle managers, the teams literature has paid no explicit attention to their outcomes. While the management literature recognizes that managers at different levels of the organization have fundamentally different roles and interests (Conger and Kotter, 1987; Schlesinger and 
Klein, 1987; Stewart, 1987), these distinctions have not been tested systematically in the literature on teams. In contrast to supervisors, however, the outcomes for middle managers appear to be theoretically ambiguous. On the one hand, they stand to gain if self-managed teams lead to better operational performance and middle managers are rewarded for implementing such innovations. Middle managers who gain a reputation as innovators or "entrepreneurial" are likely to have mobility opportunities both inside and outside the organization (Kanter, 1983). Performance studies do show that self-managed teams are associated with better performance along many dimensions (Pearce and Ravlin, 1987; Cotton, 1993; Cohen and Bailey, 1997). On the other hand, middle managers stand to lose if their jobs are made more difficult by team structures that create conflicts between workers and supervisors. There are no studies that I could identify that shed light on these plausible alternatives. For this reason I make no formal hypotheses regarding the outcomes for managers, but explore this issue in the data analysis.

\section{Offline Teams and Employee Outcomes}

In contrast to self-managed teams, which reduce hierarchical relations at work, offline problem-solving teams do little to change existing hierarchies. Because they consist of a structure that is parallel to the organization of work, they tend to complement rather than substitute for existing structures.

In theory, workers stand to gain from participation in offline teams because they provide an some opportunity for voice at work. When quality circles and quality of worklife (QWL) programs were recent innovations in the U.S., for example, Freeman (1984) highlighted their potential to satisfy the interests of employees at stakeholders in the corporation by providing them with a greater opportunity for voice (1984:147). The opportunity for employees to participate more in decisions would align their interests with those of the corporation. Freeman 
did not differentiate among different employee groups. Presumably, at each level of the organization, lower level employees would have the opportunity to voice their opinions to their superiors so that each group in the hierarchy would benefit. Overall communication, information sharing, and cooperation would result, creating greater satisfaction across groups.

The empirical research shows that worker involvement in offline teams has a fairly modest, but not consistent, positive relationship with worker attitudes, particularly satisfaction with participation in decision-making (Adam, 1991; Cotton, 1993; Griffin, 1988; Steel et. al., 1990). The most plausible interpretation of these results is that parallel structures do not sufficiently influence the organization of work and daily routines of employees to dramatically affect their attitudes and self-interests. I could find no studies of the relationship between offline team participation and worker perceptions of employment security, but in theory their security is unlikely to be affected because offline teams do not enhance the relative position or role of workers to the corporation in a substantial way.

The theoretical predictions for supervisor and managerial participation in offline teams are ambiguous. While Freeman's stakeholder theory assumed that they would benefit from participation, the participation literature often assumes that both supervisors and middle managers will be equally (and negatively) affected by any type of team participation (e.g., Fenton-O’Creevy, 1998). This perspective assumes that sharing information and consulting workers in decision-making is as threatening to supervisors as delegating decision-making. However, it is more likely that supervisors and managers experience a net effect of positive and negative dimensions of offline teams. On the one hand, offline teams may serve as constructive forum for problem-solving and conflict resolution, and subordinates may experience more opportunities for voice vis-à-vis their superiors. On the other hand, supervisors and managers 
already have opportunities to discuss issues among themselves as they arise in the course of daily business. They may experience formal meetings with subordinates as a waste of time or source of irritation. In either case, joint decision-sharing forum do not affect the existing division of labor. For example, Bradley and Hill (1987) found that quality circles produced only minor changes in the jobs of supervisors and managers or in the organizational hierarchy. In sum, given the parallel nature of offline teams, they are unlikely to affect the decision-making discretion, employment security, or satisfaction of managerial employees in a serious way. For this reason, I make no formal hypotheses regarding the relationship between offline problemsolving teams and outcomes for supervisors and managers.

Thus, the literature suggests the following hypothesis regarding offline teams:

H3: For workers, participation in offline teams will have a small positive effect on their perceptions of discretion and satisfaction.

In sum, the following model is estimated in the statistical analysis that follows: $\mathrm{Y}=\mathrm{f}$ (organizational position, offline team, self-managed team, SMT*position, HR controls, demographic controls).

\section{METHODS AND DATA}

The research strategy for this study was to examine one large corporation and to compare the outcomes of two types of team innovations for non-managerial employees, supervisors, and middle managers. This approach helps to control for organization-level variables such as corporate "culture," business strategy, and human resource and industrial relations policies. The company is a former Bell regional telephone company covering a several state area and ninety union locals. Also, because the company is unionized, the collectively-bargained contract reduced variation in many HR practices (training, seniority-based job bidding, benefits, 
compensation, etc.). This allows the effects of team innovations to be more accurately identified. The overall research combined observation, interviews at multiple levels of the organization, individual surveys, and archival data on performance matched to the individual surveys.

\section{Research Site}

The research site provided a "best case scenario" in terms of conditions likely to achieve “mutual gains” for all interested parties. The union and management had a mature bargaining relationship with a history of cooperative relations dating to the 1960s (Crane 1990). The unionmanagement partnership in the 1990s capitalized on a successful 1980 Quality of Worklife Program (QWL), which in 1990 still included 600 active joint committees involving workers, supervisors, and lower level managers. In 1992, union and management leaders negotiated an overarching Total Quality Program, which included the use of self-managed teams and offline problem-solving teams designed to improve customer service and quality. Widespread lower level support for the union-management partnership strategy is evidenced in my 1994 survey, in which 90 percent of workers, supervisors, and managers and 81 percent of local union presidents said they supported the union's participation in Total Quality. Ninety-seven percent of local union presidents were participating in monthly managerial business meetings, and 32 percent were participating in weekly management staff meetings. The environment appeared to be one of relatively widespread trust and cooperation.

In this context, experiments with self-managed teams were voluntary and left to local initiative. Supervisors, managers, and workers developed written agreements specifying what supervisory tasks teams would assume (such as daily assignments, handling non-routine problems, calling directly on subject matter experts as needed). The supervisor typically became 
a "coach,” to be called on only as needed. In network installation and repair, for example, a selfmanaged team would have full responsibility for its "turf" or geographic area. Members absorbed internal coordination and monitoring responsibilities, including daily assignments, scheduling, reporting, quality inspections, and safety reports. They also absorbed "external coordination" roles: relating directly to other managerial and professional staff in outside departments: engineering, installation and repair, the facility assignment center, cable TV and the power company (who share joint-use poles). In call centers, self-managed teams did not differ from traditionally-supervised groups along many dimensions: all employees, for example, were required to handle the same volume of calls and adhere to standardized procedures. The teams differed, however, in that the supervisor was removed, and team members were responsible for their own development, problem-solving, learning, and meeting performance goals.

Team members received additional training, but no additional pay, and remained under the same contract provisions as other workers. In fact, self-managed team members were not eligible for additional pay for “acting supervisor," a contract provision for ad hoc assumption of acting supervisor duties, which traditionally-supervised workers were eligible to receive. Team members often worked in the same locations as traditionally supervised groups. Joint teams of union and management trainers provided resources and facilitation for the transition to teams. Similarly, the offline problem-solving teams were voluntary. They were of three types: QWL teams, quality action teams, and other problem-solving teams. These teams were similar in that they involved some combination of workers, supervisors, and managers in periodic meetings; they differed somewhat in their purpose: QWL teams focused on working conditions; quality action teams on quality issues; other ad hoc problem-solving groups discussed specific 
work-related issues that arose from time to time. The teams had specific goals and timetables, covered a range of minor and major problems, and led to results that varied from trivial to quite valuable. One of the most difficult projects taken on by a team involved overseeing the shut down of an office. The team of union workers, supervisors, and managers managed the process of early retirement, training, or relocation of all of the employees at the site. While the decision to close the site created resentment among employees, the joint forum provided a vehicle for productive solutions, one that produced more catharsis than conflict among workers, supervisors, and managers, all of whom were affected by the decision.

\section{Sample}

The subjects of the study were employees in the two "core" divisions central to telecommunications operations: network operations and customer service and sales. Network operations is responsible for maintaining the transmission and switching system, with operations decentralized and geographically dispersed in small offices (usually less than 75). The skilled, autonomous, and predominantly male workforce is comprised of several sub-specialties with different skill-levels, including installation and repair techs, cable repair techs, facilities techs, outside plant techs, electronics techs, cable splicing techs, switching techs, and engineering techs. Installation and repair techs (the lowest skilled, entry level position) constitute the largest group in the company and represent $48 \%$ of sample in the study.

Customer service and sales operations, which handle customer sales, billing, and other inquiries, employ a female-dominated, semi-skilled workforce in call centers that range from 70200 in size. There are 3 main subgroups: representatives responsible for service and sales, collections, and repair. In the company, the overwhelming bulk of these employees are customer service and sales reps. In my sample, they make up $80 \%$ of the total. 
The data come from a mail survey administered to employees on company time in 1994. Top management and union leaders co-signed a cover letter urging workers to participate; supervisors and managers received a supporting letter from top management. A total of 1,191 employees returned the survey, for a response rate of 58 percent. The stratified random sample was constructed by first selecting all existing self-managed teams in network and customer service operations. There were 169 teams -- 115 among network field technicians and 54 teams among service representatives. I then used the corporate HR information system to randomly select a similar number of traditionally supervised work groups in the same locations as the selfmanaged teams. This produced a total of 330 work groups, with self-managed teams and traditional groups matched by occupation and office location. To limit the study's intrusiveness, a random subset of employees in these groups received surveys. Once the work groups were identified, their supervisors and middle managers above them were added to the sample.

The final sample includes 190 middle managers, 204 supervisors, and 797 workers. Roughly equal numbers of employees at all levels are associated with teams and traditional groups (See Table 1). Fifty percent of all respondents from network (and 40 percent from customer services) are involved with self-managed teams. Sixty-three percent of all respondents are in network; 37 percent are in customer services. The sample also is reasonably representative of the percentage of employees in the company who were in each respective management level at the time. Of the survey respondents, 33.2 percent are managers and 66.8 percent are workers. In the company, 27 percent were management and 73 percent, non-management.

[Insert Table 1 about here]

The sample of participants in offline teams was drawn from the sample of employees in self-managed and traditionally supervised groups because the company did not keep a 
centralized record of these participants (See Table 2). The survey asked employees whether or not they were currently participating in a quality action, problem solving, or quality of worklife team. On average 64.2 percent of middle managers, 53.7 percent of supervisors, and 19.6 percent of workers in this sample reported that they were participating in at least one type of offline team. Roughly equal percentages of employees associated with self-managed and traditional work groups were also involved with offline teams. Among workers, 18.9 percent of those in traditional groups and 21.1 percent of those in self-managed teams were part of offline teams. For supervisors, the corresponding participation rates were 51.8 percent and 56 percent; and for middle managers, 72 percent and 56.7 percent.

[Insert Table 2 about here]

The demographic composition of the sample generally reflects the age and gender composition of a traditional Bell company (see Table 3). The average age of the sample is 44.5 years old, and the average education, 13.5 years. Eighty-five percent of the sample is white; 44.6 percent is female; and average company tenure is 21.6 years. Across network and customer service divisions, the average education is not significantly different; but the network population is somewhat older (46.2 years versus 41.6 years), predominantly male (80 percent, versus 85 percent female in customer services), and has more company tenure (23.2 versus 18.8 years). Across management levels, the sample has predictable characteristics: with increasing level, the average age, education, tenure, male/female ratio, and white/non-white ratio increases.

\section{Dependent Variables}

The models test 3 dependent variables: perceptions of discretion, employment security, and satisfaction - all indicators of personal interest to employees. Discretion is a three-item scale that includes control over tasks, tools, and procedures (Cronbach’s alpha $=.81$ ). Employment 
security is measured by two items: the extent to which employees feel less secure on their job than they “did several years ago," (reverse coded) and their satisfaction with their current level of employment security (alpha $=.65$ ). Satisfaction is a three-item scale that includes satisfaction with participation in decision-making, the job, and promotion opportunities (alpha = .79).

\section{Independent Variables}

Management level is a series of dummy variables that represent whether the employee is a middle manager, supervisor, or worker (omitted category). Division affiliation is a dummy variable where one represents network operations, and zero is customer service and sales operation. Participation in offline teams is a measured by a dummy variable where $1=$ an employee who currently participates in offline team meetings at least once per month, including quality action teams, QWL teams, or other problem-solving teams. Self-managed team participation is a dummy variable where one is an employee who either participates as member of a team (a worker) or supervises or manages a team; zero is an employee who is member of traditionally supervised group (TSG) or supervises or manages a TSG.

To create the interaction terms, I used a series of dummy variables for each combination of work group type (e.g., self-managed team or traditional group) and management level. These categories include: workers in traditional groups (the omitted category), workers in self-managed teams (SMT workers), supervisors of self-managed teams (SMT supervisors), supervisors of traditional groups (trad. supervisors), managers of SMTs (SMT managers), and managers who were not involved in SMT innovations (trad. managers). This approach allows me to test in one regression, the outcomes for each combination of team involvement and management level. 


\section{Control Variables}

Research indicates that organizational context plays an important role in the attitudes of employees (e.g., Lawler, 1986). Important HR and IR practices, therefore, are controlled for in this study. HR practices included training, perceptions of mobility, compensation, and managerial support, and all are expected to be positively related to the outcomes of interest. Training is a measured by the number of days of training received by the employee in the two years prior to the survey. Mobility is the mean of two questions regarding the extent of change in opportunities for transfers and promotions (alpha $=.67$ ). Compensation is measured as the mid-point of annual earnings brackets (e.g., \$20,000-\$29,999, etc), and is transformed into the natural log of earnings. Managerial support is a scale of 5 items that measure the level of support provided by an employee's immediate supervisor. It includes an assessment of the supervisor's (manager's) ability to provide feedback, the frequency of feedback, support for employee participation, respect, and fairness of treatment (Cronbach’s alpha $=.84$ ). Labor relations climate is measured by a single question that asks employees to rate labor-management relations in their workplace on a 5-point scale of very poor to very good. Individual demographic variables include gender, race, years of education, job tenure and years of company service.

It is noteworthy that two of these control variables - management support and labor relations climate - may be endogenous to teams and thereby bias downwards the relationship between team participation and outcomes of interest. However, it is also plausible that work groups with better management support or better labor relations were more likely to form teams to begin with. Thus, to provide a tougher test and more conservative estimate of the relationship between teams and employee outcomes, I included these controls in the models. I also tested the 
models without these controls in analyses not shown, and I discuss these findings in the results section.

\section{RESULTS}

Table 3 reports the means, standard deviations, and pairwise correlations for all variables except demographics. Employees at higher management levels, in network operations, in offline teams, and in self-managed teams had significantly higher levels of discretion and satisfaction. Many of the control variables are also significantly correlated with the outcome variables, indicating the importance of including these controls.

\section{[Insert Table 3 about here]}

To examine the primary hypotheses, I used multivariate regression analysis with a Huber (1967) correction for clustering within work groups to produce robust standard errors. Where cluster sampling exists, as in this case, the Huber technique assumes that observations are independent across groups, but not within groups. The alternative variance estimator takes into account the correlations within groups, and thereby produces more robust standard errors. Analyses using OLS and Huber-corrected regressions produced very similar results. The Hubercorrected results are reported here.

\section{Comparing Outcomes for Workers, Supervisors, and Managers}

Table 4 reports the results for the dependent variables of discretion, employment security, and satisfaction. For each dependent variable, there are two models. The first model for each dependent variable (models $1,3,5$ ) estimates the effects of the base case of organizational status (management level, division affiliation) plus participation in offline teams (hypothesis 3). The second model $(2,4,6)$ adds the effects of participation in a self-managed team or traditionally supervised group at each management level (hypothesis 1). 
The results show that supervisors generally experienced significantly greater discretion than workers (model 1), significantly less employment security (model 3), and no difference in satisfaction (model 5). Middle managers had greater decision-making discretion and satisfaction, but significantly less employment security. These findings are consistent with the general observation that, unlike the past when managerial employees enjoyed implicit employment security, restructuring in the 1990s undermined that security. Also, as expected, being employed in network operations (the higher skilled technical side of the business) was significantly positively related to discretion and satisfaction, (but not employment security).

The results regarding offline teams do not support hypothesis 3 . That is, participation in offline teams had no significant relationship to any of the outcomes of interest for employees. Given that this represents an overall finding for all employees, I conducted separate regressions for each level of employee group (workers, supervisors, and managers). The results were insignificant for all three groups.

By contrast, the analyses generally support the hypothesized relationships between selfmanaged teams and employee outcomes (hypothesis 1). In general, self-managed teams were associated with significantly positive outcomes for workers, negative outcomes for supervisors, and modestly positive outcomes for managers (models 2, 4, and 6). Note that the coefficients for each category of employee should be interpreted in relation to the omitted category (workers in traditional groups). Thus, workers in self-managed teams had significantly greater discretion, employment security, and satisfaction than those in traditional groups.

Interpreting the results for supervisors is more complex. Recall that compared to workers in general, supervsiors had higher discretion, lower employment security, and no difference in satisfaction (models 1,3,5). However, when supervisors are disaggregated into those who 
oversee self-managed teams and those who manage traditional groups, the negative results for supervisors in general are found to be particularly driven by supervisors of self-managed teams. Supervisors of teams had significantly less employment security than did workers in traditional groups, while supervisors of traditional groups were no different from the omitted category in terms of their perceived employment security. Similarly, supervsiors of teams scored significantly lower than their traditional counterparts in terms of their overall satisfaction level. Supervisors of teams also had less discretion (coefficient of .825 over the omitted category of workers) than did their counterparts who supervised traditional groups (coefficient of .973 over the omitted category), but this difference is not statistically significant. In sum, the fact that supervisors as a group had significantly lower levels of employment security than workers as a group (model 3) and the same level of satisfaction (model 5) is driven largely, although not entirely, by the supervisors of self-managed teams.

These analyses also show that the outcomes for middle managers are quite different from those of supervisors. Managers who initiated self-managed teams showed no statistically significant difference from managers of traditional groups in terms of their decision-making discretion (coefficient of .921 versus .825) and overall satisfaction (.453 versus .417). (In separate analyses of managers only, I confirmed that these differences are not statistically significant.) However, the two groups differed with respect to perceived employment security: traditional managers perceived their job security to be significantly lower than the omitted category (workers in traditional groups). Thus, the overall negative relationship between middle managers and employment security found in model 3 is driven primarily by the negative perceptions of managers of traditional groups. 
In sum, these findings suggest that workers benefited significantly from self-managed teams, supervsiors lost out, and middle managers who initiated self-managed teams had higher levels of employment security than their more traditional counterparts.

[Insert Table 4 about here]

The results for the control variables for each dependent variable are noteworthy. With respect to the human resource and labor-management control variables, most are significant in most models and have the predicted relationship with the outcomes of interest. Given the potential endogeneity of management support and labor relations variables, I conducted the analyses without those controls. The results produced coefficients on teams that were slightly larger in size but not different with respect to levels of significance.

With respect to the demographic variables (not shown), race (Caucasian) and organizational tenure are significantly negatively related to security. Female workers have significantly higher levels of satisfaction and more educated workers have significantly lower levels. These results suggest that male workers and more educated workers are less satisfied with their jobs and opportunities.

\section{Tests of Mediation}

In Table 5, I report the results of tests of mediation (hypothesis 2). Because the causal mechanisms linking teams to satisfaction may vary across different organizational levels, I conducted separate analyses for workers and supervisors. I did not include middle managers because their levels of satisfaction did not vary by whether they participated in team innovations or not.

To consider whether discretion or perceived employment security mediate the relationship between team participation and satisfaction, I followed the procedure outlined in 
Baron and Kenny (1986:1176). First, I tested whether the independent variable (self-managed team participation) is a significant predictor of the mediating variables, discretion and security (Table 4 shows this to be true). Then, in Table 5, I examined the relationships between selfmanaged team participation, discretion, security, and satisfaction. The first models (Models 1 and 6) regress satisfaction on the control variables plus the indicator for self-managed team participation. The second models (Models 2 and 7) include controls and measures of discretion and employment security. The third models (Models 3 and 8) consider the mediating role of discretion alone, while the fourth models (Models 4 and 9) consider the role of employment security. The final models (Models 5 and 10) include both discretion and security as mediators. Partial mediation occurs when, in the presence of discretion or security, the previously significant relationship between team participation and satisfaction is reduced in size and significance. Full mediation occurs when that previous relationship becomes insignificant and is essentially reduced to zero.

The results show that the causal mechanism linking team participation and satisfaction is different for workers and supervisors. Team participation has a significant positive outcome for worker satisfaction, and that relationship is primarily mediated by the increased decision-making discretion that workers experience (in the presence of the discretion variable, the size and significance of the team participation variable decreases significantly - model 3). By comparison, there is very minimal change in the team variable in the presence of the security variable (model 4). When both mediators are added to the model (model 5), the coefficient on self-managed teams become insignificant, indicating full mediation when both discretion and security are taken into account. 
The results for supervisors are the opposite. For them, there is a negative relationship between self-managed team participation and satisfaction (model 5). Employment security is positively related to supervsisors' satisfaction (model 6); and when both indicators are added to the model, the coefficient on self-managed teams is substantially reduced in size and becomes insignificant, indicating full mediation (model 8). Thus, teams enhance workers' job satisfaction mostly by increasing their discretion at work, while they lower supervisors' job satisfaction mostly by decreasing their perceived job security.

Finally, in regression analyses not shown, I examined whether the differential outcomes of teams for workers, supervisors, and managers carried over into different attitudes towards self-managed teams as a competitive strategy. Top management in this case had campaigned for the adoption of total quality and self-managed teams as a mechanism for improving customer service and competitiveness. Adoption depended on the voluntary participation of employees at all levels. I included several survey questions regarding whether the team strategy was an effective one for improving performance and competitiveness. I found that supervisors had significantly more negative views of the team intervention than did workers.

These quantitative results are reflected in my qualitative data from interviews. For example, one call center worker noted, "In general we've gotten support from upper management, but the supervisors won't let go. The supervisor still makes the decision and we do the paper work. We're not invited in on decisions made by the supervisor. She decides overtime; we can't set our work schedule. So she basically treats the traditional and self-directed groups the same."

The regression analyses showed that middle managers also had more negative views than workers, despite the fact that they personally were not adversely affected by the innovation. 
However, given that the new team structures caused disaffection by supervisors, middle managers may have felt the innovation was not worth the conflict it caused. For example, in one qualitative interview, a manager of a call center who had experimented with the team structures concluded that she would not diffuse them to the rest of her office because her supervisors were against it.

Other qualitative evidence from the field supports the idea that the self-managed team initiative came to be viewed by many supervisors and managers as primarily a downsizing and delayering strategy aimed at them. In fact, the self-managed teams sometimes became a solution to the fact that many supervisors and managers were taking early retirement. According to one manager, "We lost so many management jobs that they backed into it [using self-managed teams]. It forced a reorganization at the bottom." But over time, the initiative became associated with top management's explicit goal of increasing spans of control and reducing bureaucracy. For example, one network manager viewed the purpose of self-managed teams as, "...increased span of control.... Traditionally in my area it was 1:5. The company wants to go to 1:30. But there's no way to supervise this many, so the duties of the supervisor have to change." Another early advocate of self-managed teams stated, "This experiment was viewed as my 'toy'. Now that were downsizing, it's being taken more seriously." Another staff manager noted, "...the broad initiative has come from operations managers who feel pressured by the head count squeeze. There's been a growth in interest at the same time that downsizing has been occurring." Thus, self-managed teams became identified as a downsizing strategy even though they sometimes began as a solution to voluntary early retirement by managers. This evidence also helps explain the quantitative results of the differences between middle managers. Those who 
introduced teams would be viewed as innovators and perceived their employment security to be higher than managers who were "traditionalists”.

\section{Examination of Alternative Explanations}

I conducted additional analyses to examine alternative explanations for the quantitative results in this study. One potential threat is a Hawthorne effect: workers in teams may have had higher satisfaction because they were treated as special. To consider this possibility, I examined whether there were systematic differences in the attitudes of early and later-forming teams. If teams members feel they are being treated specially, that treatment is likely to wear off over time as the novelty of the self-managed team experiment fades. Some researchers, for example, have found that the benefits of work innovations fade over time (Griffin, 1988; Lawler and Mohrman, 1987). In this case, the teams were formed over several years, and this variation provided the opportunity to compare employees in early and later-forming teams. About half of the teams began between 1989 and 1993, and half thereafter. Because I surveyed all teams and knew the team tenure of members and the date each team was formed, I could compare the characteristics of members of earlier and later forming teams. I found no systematic differences in the attitudes of members of early and later-forming teams.

Another explanation for the positive attitudes of workers in teams is selection bias. Joining teams was voluntary, so it could be that volunteers were more likely to have greater discretion or security or satisfaction before going into the teams. Field interviews and survey questions provide some basis for refuting this idea. First, both managers and union leaders said that they purposefully put employees with different performance levels together in teams so as to avoid the charge that self-managed teams were being favored. Also, less than 10 percent of surveyed managers said that good performance was used as a criterion for selection. Also, in 
regressions (not shown), participants in teams were no more likely to say they would accept a promotion to a higher position.

Another way to examine whether members of self-managed teams are biased systematically is to analyze whether there are differences between "volunteers" and "nonvolunteers" to teams. While I could not go back in time, I could compare current volunteers and non-volunteers. A survey question asked employees in traditional groups if they would volunteer for self-managed teams if given the opportunity by their supervisors or managers. Using this question, I substituted team-volunteers for team-members in the regression models discussed above, and found that being a volunteer for a self-managed team had no significant relationship with the outcomes of interest, supporting the interpretation that observed results reflect causal rather than selection effects.

Another possible explanation for these results is that supervisors and managers of teams differed significantly from their counterparts along dimensions that covary with team participation. I examined other dimensions of work that might influence the attitudes of supervisors and managers, including a) the importance of coaching activities; b) span of control; c) workloads and understaffing; and d) daily work hours. Supervisors of teams reported higher levels of coaching activities than supervisors of traditional groups (10.7 hours per week vs.7.1 hours) and wider spans of control span of control (20.7 versus 10.5). They were not significantly different in workloads or work hours, the latter of which averaged 9.3 hours per day. For middle managers, whether they oversaw teams or not had no relationship with their span of control (on average 37 for middle managers) or their daily work hours (which averaged 10.1 hours). In models (not shown), none of these variables explained variation in the outcomes of interest.

\section{DISCUSSION AND CONCLUSIONS}


The findings in this study may be summarized as follows. First, organizational position is significantly related to work-related attitudes, but not in entirely predictable ways. Consistent with what we know about bureaucracies, employees at higher management levels reported greater discretion and job satisfaction, but not greater employment security. This finding reflects the relative stability experienced by workers compared to managers in unionized companies, and more broadly reflects the unstable employment conditions in the 1990s - the white collar blues (Heckscher, 1995), broken promises (Osterman, 1996), or the new deal at work (Cappelli, 1999) that managerial employees faced. The difference has been particularly pronounced in unionized settings where

Second, the outcomes of offline team and self-managed team structures were dramatically different. Participation in offline teams had no significant relationship to the attitudes and interests of employees. In this case, offline problem-solving groups appeared to provide a vehicle for communication and problem solving among managerial and nonmanagerial employees. However, they did not affect the organizational hierarchy or division of labor in any substantial way. Self-managed teams, by contrast, were associated with significant differences in discretion, employment security, and satisfaction. Moreover, the outcomes were different across levels of the status hierarchy: significantly positive for workers, significantly negative for supervisors, and somewhat positive for middle managers who initiated team innovations. Moreover, it is noteworthy that among supervisors, those involved with the team innovation felt their employment security most threatened, while among managers, it was the opposite. These findings suggest that it is important to investigate the characteristics of distinct types of team formations for groups at different levels of the status hierarchy. 
Third, the ways in which the self-managed teams affected employees' satisfaction with their jobs differed significantly across management levels. The higher satisfaction among workers in teams occurred mainly through higher levels of decision-making discretion. The lower satisfaction among supervisors of teams was related primarily to their threatened employment security.

More generally, this study highlights the need to understand the introduction and outcomes of teams as they affect the division of labor in an organization, rather than viewing teams at the unit of analysis. It emphasizes the need to examine the diffusion and sustainability of organizational innovations from a political rather than strictly economic perspective. Viewed only in terms of economic performance, the self-managed team program was a success that should have been diffused across the organization. In customer service and sales call centers, workers in the self-managed teams had significantly higher monthly sales than did workers under traditional supervision (Batt, 1999). In network operations, self-managed teams of technicians absorbed the monitoring and coordination functions of their supervisors without adversely affecting productivity; and the teams did these tasks in two-thirds less time than the supervisors, resulting in significant savings in indirect labor costs (Batt, 2001). Despite these economic benefits, the company abandoned the self-managed team initiative. By contrast, the company continued the use of total quality offline teams.

The evidence in this study suggests that the self-managed teams were not sustainable for political reasons. Of the workers who were surveyed, 70 percent of those in traditional groups said they wanted to join a self-managed team. Top management supported the idea because it led to significant improvements in performance and significantly lower indirect labor costs. The union supported the innovation because it improved the working conditions and employment 
security of members. However, the shift to teams also required the voluntary cooperation of supervisors and middle managers, and the support was not forthcoming. Those supervisors that had volunteered for the program (presumably the more cooperative organizational citizens) reported significantly lower levels of decision-making discretion, security, and job satisfaction. Top management could have attempted to diffuse the program throughout the organization by making it mandatory, but chose not to. It considered using forced layoffs among supervisors and managers - an approach that would have allowed quicker implementation of teams and a streamlining of the bureaucracy. However, top management ultimately decided that forced layoffs and mandatory implementation of teams would have alienated managerial employees too much and that the risks outweighed the potential benefits. After three years of implementation, top management abandoned the joint initiative because it never diffused sufficiently enough to have a large impact on operational performance. In other words, the case represents an example in which islands of excellence failed to expand to an organization-wide strategy. Subsequently, top management focused on across-the-board reengineering and downsizing for all employees, and the longstanding union-management partnership collapsed.

\section{Limitations}

There are several limitations to this study. As indicated above, although I did several analyses that cast doubt on the idea that selection bias and Hawthorne effects are alternative explanations, they cannot be ruled out entirely. In addition, another limitation is single source survey data, in which correlations between independent and dependent variables are likely to be inflated (Roberts and Glick, 1981; Wagner and Gooding, 1987). This is less of a problem in this study because the analysis focused on the relationship between objective measures of organizational position and participation in teams (drawn from archival data) and attitudinal 
outcomes. Moreover, the self-reported participation in offline teams was not significantly related to attitudes. The results are striking in that significant differences in outcomes were found depending on whether the team formation was offline or self-managed. In addition, there are simultaneous findings of a positive relationship between teams and attitudes for nonmanagerial employees and a significant negative relationship for managerial employees.

\section{Conclusions}

This study contributes to understanding employee reactions to teams, and to the diffusion and sustainability of work innovations more broadly. First, a political perspective provides a useful lens for analyzing organizational change because it focuses attention on how work innovations affect the self-interests of multiple groups in the employment system. In this case, a focus on workers alone would not have explained why the self-managed team structures were abandoned while the offline quality action teams were kept in place. Even though they showed no significant relationship to objective performance outcomes, the offline teams were politically acceptable and provided opportunities for workers and managers to talk to one another. Selfmanaged teams, by contrast, which demonstrated significant positive effects on objective performance measures, were abandoned, in part because they lead to a much more radical restructuring of the division labor between managerial and non-managerial employees. Thus, they were not politically acceptable. In the short run, top management made a deal with top union leaders that essentially traded-off the interests of supervisors and managers for those of workers; but in the longer term, it was not willing to take on the managerial workforce.

These findings have implications for unions as well as top management. For unions, the findings suggest that it is insufficient to focus on outcomes for members alone without understanding the spillover effects for other occupational groups. Both union and management 
leaders need to understand how negotiated agreements influence the self-interests and behavior of non-union technical, professional, and managerial employees. This understanding may provide unions with a more realistic appraisal of the sustainability of workplace innovations designed to benefit members.

The generalizability of these findings is also worth discussing. As a qualitative and quantitative analysis of one large service bureaucracy, the findings are context-specific. The strength and bargaining position of the union created opportunities for member gains. It is not reasonable to conclude that self-managed teams inevitably lead to conflicts of interest or zero sum outcomes for workers and managers, particularly in greenfield sites where firms hire a new workforce and build new work systems from scratch.

The findings from this study are probably more relevant to those organizations (union and non-union alike) that have used team structures primarily to streamline layers of management - and some research suggests that this pattern has characterized many U.S. firms in the 1990s (e.g., Guzzo and Dickson, 1996). It is noteworthy that while offline problem-solving teams have continued to diffuse, the widespread interest in self-managed teams appeared to wane in the 1990s, according to some national surveys (Osterman, 1994; 2000). Particularly relevant to the current study, in a 1998 national survey of the telecommunications services industry, 94 percent of customer service centers reported using offline teams, but only 18 percent made any use of self-managed teams (Batt, 2000). Other types of teams or lean production, which are not as beneficial to production workers and which leave the organizational hierarchy intact, appear to be diffusing more widely throughout the economy. 


\section{References}

Adam, Everett E. 1991. “Quality Circle Performance.” Journal of Management 17:25-39.

Adler, Paul, and Robert Cole. 1993. "Designed for Learning: A Tale of Two Auto Plants.” Sloan Management Review (Spring):85-94.

Ancona, Deborah G., and Deborah F. Caldwell. 1992. "Bridging the Boundary: External Activity and Performance in Organizational Teams.” Administrative Science Quarterly 37:634-665.

Appelbaum, Eileen, Thomas Bailey, Peter Berg and Anne Kalleberg. 2000. Manufacturing Advantage. Ithaca, NY: Cornell University Press.

Barker, James R. 1993. “Tightening the Iron Cage: Concertive Control in Self-Managing Teams.” Administrative Science Quarterly 38:408-437.

Baron, Robert.M., and Kenny, D.A. 1986. “The Moderator-Mediator Variable Distinction in Social Psychological Research.” Journal of Personality and Social Psychology 51(6):1173-1182.

Batt, Rosemary. 1999 "Work Organization, Technology, and Performance in Customer Service and Sales.” Industrial and Labor Relations Review 52(4):539-564.

Batt, Rosemary. 2000. "Strategic Segmentation and Frontline Services: Matching Customers, Employees, and Human Resource Systems." International Journal of Human Resource Management 11(3):540-561.

Batt, Rosemary. 2001. “The Economics of Teams Among Technicians.” British Journal of Industrial Relations 39(1):1-25.

Bradley, Keith, and Stephen Hill. 1987. “Quality Circles and Managerial Interests.” Industrial Relations 26:68-82.

Buchanan, D., and Preston, D. 1991. "Life in the Cell: Supervision and Teamwork in a 'Manufacturing Systems Engineering' Environment.” Human Resource Management Journal 2(4):55-76.

Burowoy, Michael. 1979. Manufacturing Consent. Chicago: University of Chicago Press.

Cappelli, Peter. 1999. The Ne Deal at Work: Managing the Market-driven Workforce. Boston: Harvard Business School Press.

Cohen, Susan, and Diane Bailey. 1997. "What Makes Teams Work: Group Effectiveness Research from the Shop Floor to the Executive Suite.” Journal of Management 23(3):239-290.

Conger, J.A., and. Kotter, J.P. 1987. “General Managers.” In Handbook of Organizational Behavior, edited by Jay W. Lorsch, pp. 392-404. Englewood Cliffs, NJ: Prentice-Hall. 
Cotton, John L. 1993. Employee involvement: Methods for Improving Performance and Work Attitudes. Newbury Park: Sage Publications.

Crane, Donald. 1990. Patterns of Industrial Peace: Case Studies of Cooperative, Collective Bargaining Relationships. Research Monograph No. 102. Atlanta, GA: Georgia State Press.

Denison, D. R. 1982. “Sociotechnical Design and Self-Managing Work Groups: The Impact on Control.” Journal of Organizational Behavior 3:297-314.

Emery, F. E. 1980. “Designing Sociotechnical Systems for 'Greenfield’ Sites.” Journal of Occupational Behaviour 1:19-27.

Fenton-O'Creevy, Mark. 1998. "Employee Involvement and the Middle Manager: Evidence from a Survey of Organizations.” Journal of Organizational Behavior 19:67-84.

Freeman, R. Edward. 1984. Strategic Management: A Stakeholder Approach. Boston: Pitman.

Griffin, Ricky W. 1988. “Consequences of Quality Circles in an Industrial Setting: A Longitudinal Assessment.” Academy of Management Journal 31(2):338-358.

Guzzo, R. A., and Dickson, M. W. 1996. “Teams in Organiszations: Recent Research on Performance and Effectiveness.” Annual Review of Psychology 47:307-338.

Hackman, J. Richard. 1987. “The Design of Work Teams.” In Handbook of Organizational Behavior, edited by Jay. W. Lorsch, pp. 315-342. Englewood Cliffs, NJ: Prentice-Hall.

Heckscher, Charles. 1995. White collar blues. New York: Basic Books.

Heller, Frank, Pusic E., Strauss G., and Bernhard Wilpert. 1998. Organizational participation: Myth and reality. Oxford: Oxford University Press.

Huber, P. J. 1967. “The Behavior of Maximum Likelihood Estimates Under Non-standard Conditions.” Proceedings of the Fifth Berkeley Symposium on Mathematical Statistics and Probability 1: 221-233.

Kanter, Rosabeth Moss. 1983. The Change Master: Innovation for Productivity in the American Corporation. New York: Simon and Schuster.

Kerr, Steven, Kenneth D Hill, and Laurie Broedling. 1986. “The First-Line Supervisor: Phasing Out or Here to Stay?” Academy of Management Review 11(1):103-117.

Klein, Janice A. 1984. "Why Supervisors Resist Employee Involvement.” Harvard Business Review (September-October):87-96. 
Klein, Janice A., and Pamela A. Posey. 1990. "Traditional Versus New Work Systems Supervision: Is there a Difference?” In Revitalizing Manufacturing: Text and Cases, edited by Janice A. Klein. Homewood, IL: Richard D. Irwin, Inc.

Lawler, Edward E. III. 1986. High-InvolvementMmanagement: Participative Strategies for Improving Organizational Performance. San Francisco, CA: Jossey-Bass.

Lawler, Edward E. III, and Susan A. Mohrman. 1987. "Quality Circles: After the Honeymoon.” Organizational Dynamics 15 (Spring):42-54.

Lawler, Edward. E. III, Susan A. Mohrman, andGerald Ledford. 1995. Creating High Performance Organizations: Practices and Results of Employee Involvement and Total Quality Management in Fortune 1000 Companies. San Francisco: Jossey-Bass.

Leana, Carrie R. 1987. "Power Relinquishment versus Power Sharing: Theoretical Clarification and Empirical Comparison of Delegation and Participation. Journal of Applied Psychology 72(2):228-233.

Levine, David, and Laura D’Andrea Tyson. 1990. "Participation, Productivity, and the Firm's Environment.” In Paying for Productivity, edited by Alan Blinder. Washington, DC: Brookings Institution.

Lincoln, James, and Anne Kalleberg. 1990. Culture, Control, and Commitment: A Study of Work Organization and Work Attitudes in the United States and Japan. Cambridge, MA: Cambridge University Press.

Lowe, James. 1993. "Manufacturing Reform and the Changing Role of the Production Supervisor: The Case of the Automobile Industry.” Journal of Management Studies 30(5) (September):2322-2380.

Manz, Charles, and Henry P. Sims, Jr. 1987. "Leading Workers to Lead Themselves: The External Leadership of Self-Managing Work Teams. Administrative Science Quarterly 32(1):106-129.

Mowday, Richard T., Richard M. Steers, and Lyman W. Porter. 1982. Employee-Organization Linkages: The Psychology of Commitment, Absenteeism, and Turnover. New York: Academic Press.

Muller-Jentsch, W. 1995. “Germany: From Collective Voice to Co-Management.” In Works Councils, edited by Joel Rogers and Wolfgang Streeck, pp. 53-69. Chicago: University of Chicago Press.

Osterman, Paul. 1994. "How Common is Workplace Transformation and Who Adopts It?" Industrial and Labor Relations Review 47:173-188. 
Osterman, Paul. 1996. Broken Ladders: Changing Managerial Careers and Internal Labor Markets. Oxford: Oxford University Press.

Osterman, Paul. 2000. "Work Organization in an Era of Restructuring: Trends in Diffusion and Impacts on Employee Welfare." Industrial and Labor Relations Review 53(2):179-196.

Roberts, Karlene H., and William Glick. 1981. "The Job Characteristics Approach to Task Design: A Critical Review." Journal of Applied Psychology 66(2):193-217.

Roy, Donald. 1953. "Work Satisfaction and Social Reward in Quota Achievement." American Sociological Review 18:507-514.

Schlesinger, Leonard A. 1982. Quality of Work Life and the Supervisor. New York: Praeger.

Schlesinger, Leonard A., and Janice A. Klein. 1987. "The First-Line Supervisor: Past, Present, and Future.” In Handbook of Organizational Behavior, edited by Jay W. Lorsch, pp. 370-384. Englewood Cliffs, NJ: Prentice-Hall,.

Steel, Robert P., Kenneth R. Jennings, and James T. Lindsey. 1990. "Quality Circle Problem Solving and Common Cents: Evaluation Study Findings from a United States Mint.” Journal of Applied Behavioral Science 26(3):365-382.

Stewart, G. L., and Manz, C. C. 1997. "Understanding and Overcoming Supervisor Resistance During the Transition to Employee Empowerment." Research in Organizational Change and Development 10:169-196.

Stewart, R. 1987. “Middle Managers: Their Jobs and Behavior.” In Handbook of Organizational Behavior, edited by Jay W. Lorsch, pp. 385-391. Englewood Cliffs, NJ: Prentice-Hall.

Wagner, John A., and Richard Z. Gooding. 1987. "Effects of Societal Trends on Participation Research.” Administrative Science Quarterly 32:241-262.

Walton, Richard E., and Leonard A. Schlesinger. 1979. "Do Supervisors Thrive in Participative Work Systems?” Organizational Dynamics (Winter):25-38. 


\section{Table 1}

Survey Participants:

By Management Level, Division, and Association with Traditional Groups (TSG) or Self-Managed Teams (SMT)

\begin{tabular}{|c|c|c|c|c|c|c|c|}
\hline Management & Both Business & \multicolumn{3}{|c|}{ Network Operations } & \multicolumn{3}{|c|}{ Customer Services } \\
\hline Level & Units & All & $\underline{\text { TSG }}$ & $\underline{\text { SMT }}$ & All & $\underline{\mathrm{TSG}}$ & $\underline{\text { SMT }}$ \\
\hline & No. $\%$ & $\%$ & $\%$ & $\%$ & $\%$ & $\%$ & $\%$ \\
\hline Middle Managers & 19016.0 & 11.7 & 5.5 & 6.1 & 4.3 & 2.3 & 2.0 \\
\hline Supervisors & 20417.2 & 12.0 & 6.7 & 5.3 & 5.2 & 2.9 & 2.4 \\
\hline Total Managers & 39433.2 & 23.7 & 12.3 & 11.4 & 9.5 & 5.1 & 4.4 \\
\hline Workers & $797 \quad 66.8$ & 39.1 & 19.1 & 20.1 & 27.7 & 17.0 & 10.7 \\
\hline Total & $1,191 \quad 100.0$ & 62.8 & 31.3 & 31.5 & 37.2 & 22.2 & 15.0 \\
\hline
\end{tabular}

*Percentages are all in relation to the total number of respondents $(1,191)$. 
Table 2

Percent of Sample Who Participated in Offline Teams:

By Management Level, Division, and Association with Traditional Groups (TSG) or Self-Managed Teams (SMT)

Job Category

All

$\underline{\text { TSG }}$

$\underline{\text { SMT }}$

Middle Managers

Network Operations

74.8

35.3

78.8

71.2

Customer Service

-----

55.6

12.5

All Middle Managers

64.2

72.0

56.7

$\underline{\text { Supervisors }}$

Network Operations

53.2

56.3

50.8

Customer Service

41.2

67.9

All Supervisors

53.7

51.8

56.0

Workers:

Network Operations

17.6

15.4

22.7

19.8

Customer Service

23.0

-----

23.6

All Workers

19.6

18.9

21.1 


\begin{tabular}{|c|c|c|c|c|c|c|c|c|c|c|c|c|c|c|c|c|c|c|c|c|c|}
\hline & Variable & Mean & SD & 1 & 2 & 3 & 4 & 5 & 6 & 7 & 8 & 9 & 10 & 11 & 12 & 13 & 14 & 15 & 16 & 17 & 18 \\
\hline 1 & Discretion & 3.06 & 1.10 & 1.00 & & & & & & & & & & & & & & & & & \\
\hline 2 & Security & 2.01 & 0.94 & 0.09 & 1.00 & & & & & & & & & & & & & & & & \\
\hline 3 & Satisfaction & 3.06 & 0.95 & 0.45 & 0.39 & 1.00 & & & & & & & & & & & & & & & \\
\hline 4 & Supervisor & 0.17 & 0.38 & 0.23 & -0.04 & 0.07 & 1.00 & & & & & & & & & & & & & & \\
\hline 5 & Middle mngr. & 0.16 & 0.37 & 0.26 & -0.05 & 0.18 & -0.20 & 1.00 & & & & & & & & & & & & & \\
\hline 6 & Division & 0.63 & 0.48 & 0.26 & -0.06 & 0.12 & 0.07 & 0.09 & 1.00 & & & & & & & & & & & & \\
\hline 7 & Offline team & 0.33 & 0.47 & 0.16 & -0.02 & 0.10 & 0.21 & 0.29 & 0.07 & 1.00 & & & & & & & & & & & \\
\hline 8 & Self-mngd.team & 0.46 & 0.50 & 0.18 & 0.02 & 0.10 & -0.02 & 0.04 & 0.09 & 0.01 & 1.00 & & & & & & & & & & \\
\hline 9 & SMT worker & 0.31 & 0.46 & 0.01 & 0.07 & 0.03 & -0.30 & -0.29 & 0.03 & -0.17 & 0.71 & 1.00 & & & & & & & & & \\
\hline 10 & Trad.worker & 0.36 & 0.48 & -0.38 & 0.00 & -0.22 & -0.34 & -0.33 & -0.16 & -0.22 & -0.70 & -0.50 & 1.00 & & & & & & & & \\
\hline 11 & SMT super. & 0.08 & 0.27 & 0.12 & -0.07 & 0.01 & 0.63 & -0.13 & 0.04 & 0.14 & 0.31 & -0.19 & -0.22 & 1.00 & & & & & & & \\
\hline 12 & Trad. Super. & 0.09 & 0.29 & 0.18 & 0.02 & 0.08 & 0.71 & -0.14 & 0.05 & 0.13 & -0.30 & -0.22 & -0.24 & -0.09 & 1.00 & & & & & & \\
\hline 13 & SMT Mngr. & 0.08 & 0.27 & 0.19 & 0.00 & 0.13 & -0.14 & 0.68 & 0.08 & 0.15 & 0.32 & -0.20 & -0.22 & -0.09 & -0.10 & 1.00 & & & & & \\
\hline 14 & Trad. Mngr. & 0.08 & 0.27 & 0.16 & -0.07 & 0.12 & -0.13 & 0.67 & 0.05 & 0.24 & -0.27 & -0.19 & -0.22 & -0.08 & -0.09 & -0.09 & 1.00 & & & & \\
\hline 15 & Training & 11.28 & 13.09 & 0.19 & 0.05 & 0.17 & 0.14 & 0.23 & -0.01 & 0.18 & 0.11 & -0.08 & -0.21 & 0.15 & 0.05 & 0.19 & 0.12 & 1.00 & & & \\
\hline 16 & Mobility & 1.22 & 0.39 & 0.06 & 0.23 & 0.26 & -0.03 & -0.05 & -0.01 & -0.05 & -0.03 & 0.01 & 0.05 & -0.03 & -0.01 & -0.05 & -0.02 & -0.02 & 1.00 & & \\
\hline 17 & Earnings (ln) & 10.66 & 0.33 & 0.30 & 0.02 & 0.16 & 0.17 & 0.56 & 0.33 & 0.16 & 0.00 & -0.26 & -0.31 & 0.08 & 0.15 & 0.37 & 0.39 & 0.14 & -0.04 & 1.00 & \\
\hline 18 & Mgnt. support & 3.53 & 0.93 & 0.14 & 0.20 & 0.36 & 0.03 & 0.04 & -0.15 & 0.03 & -0.06 & -0.09 & 0.03 & 0.02 & 0.02 & 0.02 & 0.03 & 0.11 & 0.08 & -0.02 & 1.00 \\
\hline 19 & LM Relations & 3.40 & 0.92 & 0.29 & 0.12 & 0.41 & 0.12 & 0.18 & 0.03 & 0.11 & 0.03 & -0.07 & -0.16 & 0.06 & 0.10 & 0.13 & 0.12 & 0.10 & 0.08 & 0.14 & 0.40 \\
\hline
\end{tabular}

All values $>|.06|$ are statistically significant at $\mathrm{p}<.05$. Demographic controls not included. 

Table 4:

Predictors of Decision-making Discretion, Employment Security and Satisfaction

\begin{tabular}{|c|c|c|c|c|c|c|}
\hline & \multicolumn{2}{|c|}{ Discretion } & \multicolumn{2}{|c|}{ Employment Security } & \multicolumn{2}{|c|}{ Satisfaction } \\
\hline & Equ. 1 & Equ. 2 & Equ. 3 & Equ. 4 & Equ. 5 & Equ. 6 \\
\hline \multicolumn{7}{|c|}{ Organizational Position } \\
\hline Supervisor & $\begin{array}{l}0.638 \text { *** } \\
(0.088)\end{array}$ & & $\begin{array}{l}-0.306^{\star * *} \\
(0.084)\end{array}$ & & $\begin{array}{r}0.103 \\
(0.079) \\
\end{array}$ & \\
\hline Manager & $\begin{array}{l}0.608 \text { *** } \\
(0.119)\end{array}$ & & $\begin{array}{l}-0.466^{\star * *} \\
(0.113)\end{array}$ & & $\begin{array}{l}0.281 \text { ** } \\
(0.104)\end{array}$ & \\
\hline Division & $\begin{array}{l}0.475^{\star * *} \\
(0.096)\end{array}$ & $\begin{array}{l}0.435^{\star * *} \\
(0.092)\end{array}$ & $\begin{array}{l}-0.066 \\
(0.083) \\
\end{array}$ & $\begin{array}{l}-0.082 \\
(0.082) \\
\end{array}$ & $\begin{array}{l}0.316 \text { *** } \\
(0.076)\end{array}$ & $\begin{array}{l}0.295^{\star * *} \\
(0.074)\end{array}$ \\
\hline \multicolumn{7}{|c|}{ Team Reorganization } \\
\hline Offline team & $\begin{array}{l}-0.036 \\
(0.070) \\
\end{array}$ & $\begin{array}{l}-0.040 \\
(0.067) \\
\end{array}$ & $\begin{array}{r}0.018 \\
(0.063) \\
\end{array}$ & $\begin{array}{r}0.032 \\
(0.063) \\
\end{array}$ & $\begin{array}{r}0.027 \\
(0.055) \\
\end{array}$ & $\begin{array}{r}0.027 \\
(0.054) \\
\end{array}$ \\
\hline SMT worker & & $\begin{array}{l}0.531^{\star * *} \\
(0.088)\end{array}$ & & $\begin{array}{l}0.159 * \\
(0.073)\end{array}$ & & $\begin{array}{l}0.296 \text { *** } \\
(0.069)\end{array}$ \\
\hline SMT supervisor & & $\begin{array}{l}0.825^{\star \star \star} \\
(0.110)\end{array}$ & & $\begin{array}{l}-0.386^{\star \star *} \\
(0.109)\end{array}$ & & $\begin{array}{r}0.150 \\
(0.106) \\
\end{array}$ \\
\hline Trad. supervisor & & $\begin{array}{l}0.974^{\star \star \star} \\
(0.103)\end{array}$ & & $\begin{array}{l}-0.087 \\
(0.112) \\
\end{array}$ & & $\begin{array}{l}0.341^{\star * \star} \\
(0.095)\end{array}$ \\
\hline SMT manager & & $\begin{array}{l}0.931^{\star * \star} \\
(0.135)\end{array}$ & & $\begin{array}{l}-0.215 \\
(0.138) \\
\end{array}$ & & $\begin{array}{l}0.453^{\star * \star} \\
(0.120)\end{array}$ \\
\hline Trad.manager & & $\begin{array}{l}0.825^{\star \star *} \\
(0.132)\end{array}$ & & $\begin{array}{l}-0.558 * \star * \\
(0.125)\end{array}$ & & $\begin{array}{l}0.417^{\star \star *} \\
(0.121)\end{array}$ \\
\hline \multicolumn{7}{|l|}{ HR/IR Context } \\
\hline Training & $\begin{array}{l}0.008^{\star \star *} \\
(0.002)\end{array}$ & $\begin{array}{l}0.006 \text { ** } \\
(0.002)\end{array}$ & $\begin{array}{l}0.006 \text { * } \\
(0.002)\end{array}$ & $\begin{array}{l}0.005 \text { * } \\
(0.002)\end{array}$ & $\begin{array}{l}0.006^{\star \star *} \\
(0.002)\end{array}$ & $\begin{array}{l}0.006^{\star \star *} \\
(0.002)\end{array}$ \\
\hline Mobility & $\begin{array}{c}0.186 * \\
(0.076)\end{array}$ & $\begin{array}{l}0.193 \text { ** } \\
(0.071)\end{array}$ & $\begin{array}{l}0.503^{\star * *} \\
(0.084)\end{array}$ & $\begin{array}{l}0.507 * \star * \\
(0.083)\end{array}$ & $\begin{array}{l}0.549 \text { *** } \\
(0.067)\end{array}$ & $\begin{array}{l}0.553 \text { *** } \\
(0.066)\end{array}$ \\
\hline Earnings (ln) & $\begin{array}{r}0.112 \\
(0.129) \\
\end{array}$ & $\begin{array}{r}0.125 \\
(0.125) \\
\end{array}$ & $\begin{array}{l}0.438^{\star \star *} \\
(0.131)\end{array}$ & $\begin{array}{l}0.444^{\star * *} \\
(0.130)\end{array}$ & $\begin{array}{r}0.178 \\
(0.120) \\
\end{array}$ & $\begin{array}{r}0.178 \\
(0.118) \\
\end{array}$ \\
\hline Mngt. support & $\begin{array}{l}0.102 \text { ** } \\
(0.039)\end{array}$ & $\begin{array}{l}0.122 \text { *** } \\
(0.038)\end{array}$ & $\begin{array}{l}0.166^{\star * *} \\
(0.031)\end{array}$ & $\begin{array}{l}0.174^{\star \star *} \\
(0.031)\end{array}$ & $\begin{array}{l}0.247^{* * *} \\
(0.033)\end{array}$ & $\begin{array}{l}0.258 \text { *** } \\
(0.033)\end{array}$ \\
\hline Labor relations & $\begin{array}{l}0.197 \text { *** } \\
(0.040)\end{array}$ & $\begin{array}{l}0.179 * \star * \\
(0.038)\end{array}$ & $\begin{array}{r}0.061 \\
(0.033) \\
\end{array}$ & $\begin{array}{r}0.053 \\
(0.032) \\
\end{array}$ & $\begin{array}{l}0.265^{\star * *} \\
(0.032)\end{array}$ & $\begin{array}{l}0.255^{* * *} \\
(0.031)\end{array}$ \\
\hline Constant & $\begin{array}{l}-0.585 \\
(1.369) \\
\end{array}$ & $\begin{array}{l}-0.902 \\
(1.315) \\
\end{array}$ & $\begin{array}{l}-3.626^{\star *} \\
(1.413)\end{array}$ & $\begin{array}{l}-3.706^{\star *} \\
(1.408)\end{array}$ & $\begin{array}{l}-1.239 \\
(1.277) \\
\end{array}$ & $\begin{array}{l}-1.332 \\
(1.261) \\
\end{array}$ \\
\hline Sample & 1100 & 1100 & 1101 & 1101 & 1096 & 1096 \\
\hline Prob $>$ F & $25.370^{\star \star \star}$ & $26.540^{\star \star \star}$ & $10.240^{\star \star \star}$ & 10.160 *** & 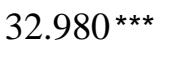 & $32.330 * \star *$ \\
\hline R-squared & 0.253 & 0.292 & 0.124 & 0.139 & 0.311 & 0.330 \\
\hline
\end{tabular}

S.E in parenthesis. $* * *=\mathrm{p}<.001 ; * *=$ p. $<.01 ; *=$ p. $<.05$. Controls for demographics not shown. 
Table 5:

Mediated Models of Teams and Employee Satisfaction

\begin{tabular}{|c|c|c|c|c|c|c|c|c|c|c|}
\hline & \multicolumn{5}{|c|}{ Workers' Satisfaction } & \multicolumn{5}{|c|}{ Supervisors' Satisfaction } \\
\hline & Equ. 1 & Equ. 2 & Еqu. 3 & Equ. 4 & Equ. 5 & Equ. 6 & Еqu. 7 & Equ. 8 & Еqu. 9 & $\begin{array}{r}\text { Equ. } \\
10\end{array}$ \\
\hline Division & $\begin{array}{l}0.383 * * * \\
(0.095)\end{array}$ & $\begin{array}{l}0.249 * * \\
(0.084)\end{array}$ & $\begin{array}{c}0.187 * \\
(0.087)\end{array}$ & $\begin{array}{l}0.435 * * * \\
(0.092)\end{array}$ & $\begin{array}{l}0.248 * * \\
(0.084)\end{array}$ & $\begin{array}{r}0.108 \\
(0.154) \\
\end{array}$ & $\begin{array}{r}0.106 \\
(0.152) \\
\end{array}$ & $\begin{array}{r}0.109 \\
(0.152) \\
\end{array}$ & $\begin{array}{r}0.101 \\
(0.154) \\
\end{array}$ & $\begin{array}{r}0.109 \\
(0.153) \\
\end{array}$ \\
\hline Offline team & $\begin{array}{r}0.088 \\
(0.074)\end{array}$ & $\begin{array}{r}0.072 \\
(0.063)\end{array}$ & $\begin{array}{r}0.078 \\
(0.065)\end{array}$ & $\begin{array}{r}0.078 \\
(0.069)\end{array}$ & $\begin{array}{r}0.068 \\
(0.062)\end{array}$ & $\begin{array}{l}-0.033 \\
(0.105)\end{array}$ & $\begin{array}{l}-0.058 \\
(0.105)\end{array}$ & $\begin{array}{l}-0.043 \\
(0.105)\end{array}$ & $\begin{array}{l}-0.047 \\
(0.104)\end{array}$ & $\begin{array}{l}-0.057 \\
(0.105)\end{array}$ \\
\hline SMT & $\begin{array}{l}0.260 * * * \\
(0.067)\end{array}$ & & $\begin{array}{c}0.132 * \\
(0.059)\end{array}$ & $\begin{array}{l}0.211 * * * \\
(0.062)\end{array}$ & $\begin{array}{r}0.094 \\
(0.056)\end{array}$ & $\begin{array}{l}-0.223 * \\
(0.105)\end{array}$ & & $\begin{array}{l}-0.203 * \\
(0.102)\end{array}$ & $\begin{array}{l}-0.130 \\
(0.105)\end{array}$ & $\begin{array}{l}-0.113 \\
(0.108)\end{array}$ \\
\hline Discretion & & $\begin{array}{l}0.262 * * * \\
(0.027)\end{array}$ & $\begin{array}{l}0.268 * * * \\
(0.029)\end{array}$ & & $\begin{array}{l}0.252 * * * \\
(0.027)\end{array}$ & & $\begin{array}{c}0.134+ \\
(0.080)\end{array}$ & $\begin{array}{c}0.161+ \\
(0.086)\end{array}$ & & $\begin{array}{r}0.127 \\
(0.080) \\
\end{array}$ \\
\hline Security & & $\begin{array}{l}0.297 * * * \\
(0.028)\end{array}$ & & $\begin{array}{l}0.310 * * * \\
(0.030)\end{array}$ & $\begin{array}{l}0.294 * * * \\
(0.028)\end{array}$ & & $\begin{array}{l}0.282 * * * \\
(0.060)\end{array}$ & & $\begin{array}{l}0.279 * * * \\
(0.060)\end{array}$ & $\begin{array}{l}0.269 * * * \\
(0.062)\end{array}$ \\
\hline Constant & $\begin{array}{r}2.352 \\
(1.561) \\
\end{array}$ & $\begin{array}{c}2.927 * \\
(1.293) \\
\end{array}$ & $\begin{array}{r}1.610 \\
(1.470) \\
\end{array}$ & $\begin{array}{r}3.504 * \\
(1.373) \\
\end{array}$ & $\begin{array}{r}2.768 * \\
(1.295) \\
\end{array}$ & $\begin{array}{l}-1.141 \\
(3.559) \\
\end{array}$ & $\begin{array}{l}-1.695 \\
(3.270) \\
\end{array}$ & $\begin{array}{l}-1.613 \\
(3.608) \\
\end{array}$ & $\begin{array}{r}-1.048 \\
(3.189) \\
\end{array}$ & $\begin{array}{l}-1.359 \\
(3.258) \\
\end{array}$ \\
\hline Sample & 732 & 730 & 731 & 731 & 730 & 189 & 188 & 188 & 189 & 188 \\
\hline Prob $>$ F & $26.00 * * *$ & $52.62 * * *$ & $37.15 * * *$ & $41.04 * * *$ & $49.74 * * *$ & $12.99 * * *$ & $14.18 * * *$ & $11.45 * * *$ & $15.41 * * *$ & $14.93 * * *$ \\
\hline R-squared & 0.337 & 0.491 & 0.416 & 0.423 & 0.493 & 0.362 & 0.434 & 0.375 & 0.430 & 0.438 \\
\hline
\end{tabular}

S.E in parenthesis. $* * *=\mathrm{p}<.001 ; * *=\mathrm{p} .<.01 ; *=\mathrm{p} .<.05$. Controls for HR/IR context and demographics not shown. 


\section{APPENDIX A: Definition of Variables}

\section{Dependent Variables}

Discretion: is a scale formed from 3 items (Cronbach's alpha $=.81$ ):

"Please tell us how much personal influence you have over the following things:

a. Deciding what tasks or work assignments you do.

b. Deciding what tools or procedures you use.

c. Controlling the pace or speed at which you work."

$(1=$ none to $5=$ complete $)$

Employment security: is a scale formed from 2 items (Cronbach's alpha $=.65$ ):

"To what extent do you agree or disagree with this statement: 'I feel less secure in my job now than I did several years ago."' (1 =strongly agree to 5 = strongly disagree)

"How satisfied are you with your employment security?"

( 1 = very dissatisfied to 5 = very satisfied $)$

Satisfaction: is a scale composed 3 questions (Cronbach's alpha $=.79$ ):

"How satisfied are you with your involvement in decisions that affect your job?"

"How satisfied are you with your opportunities for getting a better job in this company?"

"Considering everything, how satisfied are you with your job?"

( 1 = very dissatisfied to 5 = very satisfied $)$

\section{Independent Variables}

Management Level: is a series of dummy variables, for service workers, (omitted variable), firstline supervisors, and second level managers.

Division: is a dummy variable, where $1=$ network , and $0=$ customer service and sales.

Self-Managed Team Participation: a dummy variable where

1 = employee is member of self-managed teams or supervises or manages a team; $0=$ employee is member of traditionally-supervised group or supervises or manages the TSG.

Offline Team Participation: whether respondent participates in monthly meetings for quality improvement teams, quality of worklife teams, labor-management teams, or other problemsolving groups

\section{Control Variables}

Training: the number of total days of company-provided training in 2 years, including technical, basic skills (math, reading, etc.), quality, or self-managed team training (for each category)

$0=$ no training

$1=1-2$ days (recoded to 1.5 )

$2=3-5$ days (recoded to 4 )

$3=6-10$ days (recoded to 8 )

$4=11-20$ days (recoded to 15 )

5 = 20 days or more (recoded to 22) 
Mobility: the mean of two questions asking the extent to which opportunities have changed for promotions and for transfers to other locations, departments, or job titles in the prior 2 years (alpha $=.67))$ :

$1=$ declined

$2=$ about the same

$3=$ improved

Compensation: "What are your annual earnings (including overtime)?"

$$
\begin{aligned}
& 1=\text { under } 20,000 \text { (recoded to } 15,000) \\
& 2=20,000-29,999 \text { (recoded to } 25,000) \\
& 3=30,000-39,999 \text { (recoded to } 35,000) \\
& 4=40,000-49,999 \text { (recoded to } 45,000) \\
& 5=50,000-59,999 \text { (recoded to } 55,000) \\
& 6=60,000-79,999 \text { (recoded to } 70,000) \\
& 7=80,000-99,999 \text { (recoded to } 90,000) \\
& 8=\text { over } 100,000 \text { (recoded to } 110,000)
\end{aligned}
$$

Managerial Support: a scale composed of the following assessments of employee's immediate supervisor or coach (Cronbach's alpha $=.84$ ).
a. Encourages me to participate in solving problems which affect my work;
b. Knows enough about my work to accurately evaluate my performance;
c. Gives me feedback frequently enough so that I know how I am performing;
d. Treats employees with respect;
e. Puts quality above other objectives such as budgets or schedules.
$(1=$ almost never to $5=$ almost always $)$

\section{Labor-Management Climate}

"In general, how would you describe relations in your workplace between management and craft [non-managerial] employees?" ( 1 = very poor to 5 = very good) 